\title{
Amazolachesilla, a new genus of Eolachesillinae (Insecta: Psocodea:"Psocoptera": Lachesillidae) from Amazonas, Brazil
}

\author{
Alfonso N. García ALDRETE ${ }^{1}$; Edward L. MOCKFORD²
}

\section{ABSTRACT}

Amazolachesilla, a new genus in Graphocaeciliini (Lachesillidae: Eolachesillinae), from Amazonas, Brazil, is here described and illustrated. It presents an autapomorphic clunial shelf and clunial projections, as well as a peculiar male epiproct, and paraprocts with a sclerotized longitudinal rod that makes it unique in the tribe.

KEYWORDS: Graphocaeciliini, taxonomy, South America, neotropics.

\section{Amazolachesilla, um gênero novo de Eolachesillinae (Insecta: Psocodea: 'Psocoptera': Lachesillidae) do Amazonas, Brasil.}

\section{RESUMO}

O gênero novo Amazolachesilla, do estado do Amazonas, Brasil, é descrito e ilustrado. Pertence à Graphocaeciliini (Lachesillidae: Eolachesillinae). Possui uma projeção clunial média e projeçôes laterais autapomórficas, bem como machos com um epiprocto peculiar e paraprocto com uma haste longitudinal esclerosada, únicos dentro da tribo.

PALAVRAS-CHAVE: Graphocaeciliini, taxonomia, América do Sul, neotrópico. 


\section{INTRODUCTION}

The known genera of the subfamily Eolachesillinae (Psocoptera: Lachesillidae), are predominantly South American, extending north as far as the USA and northeast into the Caribbean (Mockford and Sullivan 1986; García Aldrete 2006). Two males from Amazonas, Brazil, have recently come to our attention, they belong to Graphocaeciliini of the Eolachesillinae and represent a new genus, that is here described and illustrated. The subfamily Eolachesillinae includes the tribes Eolachesillini, Waoraniellini and Graphocaeciliini; the latter with the recent genera Anomopsocus Roesler, Antilachesilla Mockford \& Sullivan, Graphocaecilius Enderlein, Mesolachesilla Mockford \& Sullivan, Nanolachesilla Mockford \& Sullivan, Notolachesilla Mockford \& Sullivan, Prolachesilla Mockford \& Sullivan and Tricholachesilla Mockford \& Sullivan. Of those, the first, the third, the sixth and the seventh ones occur in Amazonia. The genera of Graphocaeciliini are characterized as follows: With or without ocelli. Epistomal suture developed only laterally, never present dorsally. Lacinia bicuspid, with external cusp bidentate. Tarsi two segmented. Rs fork stem in forewing somewhat flexuous; Rs-M junction in forewing relatively long. Hypandrium generally with two, in some forms four, setae decidedly longer than others. Endophallic sclerites variable, at least two chelate except in forms with all very small. Ovipositor valvulae reduced: V2 never present as an entity separate from V3. Female paraproct lacking a row of long setae running its length below sense cushion (Mockford and Sullivan 1986).

\section{MATERIALS AND METHODS}

The two specimens available for study were dissected in $80 \%$ ethyl alcohol, and their parts (head, wings, and genitalia) were mounted on slides in Canada balsam. Color was recorded by placing the whole specimens, before dissection, in $80 \%$ ethyl alcohol, under the dissecting microscope, at 80X, illuminated with white cold light. Standard measurements, given in $\mu \mathrm{m}$ were taken on the slides, with a filar micrometer mounted on the optic microscope; the measuring unit is 1.36 $\mu \mathrm{m}$ for wings and $0.53 \mu \mathrm{m}$ for other parts. Abbreviations of body parts measured are as follows: FW and HW, lengths of right fore- and hind- wings; F, T, t1 and t2, lengths of femur, tibia and tarsomeres 1 and 2 of right hind leg, ctt 1 , number of ctenidia on $t 1$ of right hind leg, $f 1 . . f n$, lengths of flagellomeres $1 . . . n$ of right antenna, IO, D, and d, minimum distance between compound eyes, antero-posterior and transverse diameter, respectively, of right compound eye in front view of head, PO: $d / D$. The types belong to the Instituto Nacional de Pesquisas da Amazônia (INPA), Manaus, Amazonas, Brazil.

\section{RESULTS}

\section{Amazolachesilla new genus}

(Figures 1-5)

Diagnosis. With the characters of the tribe (Mockford and Sullivan 1986), plus the following: Ocelli absent. Rs fork stem of forewing slightly sigmoid. All forewing veins (except $\mathrm{Cu} 2$ ) and entire margin with visible setae. Membrane of pterostigma with scattered setae. Microvestiture of anterior margin of forewing type 1 (e.g. scales of low relief, rounded or bluntly pointed at their distal ends. A distinct trough evident along the outer surface of each scale, running its entire length, so that the apex is divided; see Mockford and Sullivan 1986). Hindwing without setae on veins but with small setae along margin, more conspicuous distal to the R1 junction.

Male genitalic characters. Hypandrium broad, simple, setose, posterior border slightly concave, postero-lateral corners projected posteriorly. Phallosome with basal stem, external parameres broad, articulated to distal ends of phallosome side struts, distally curved inward, the tips bearing pores (Figure 4). Aedeagal arch well sclerotized, with basal articulation to the side struts membranous. Endophallus with small anterior pair and large posterior pair of sclerites, joined by a longitudinal, slender, sclerotized band (Figure 4). Clunial shelf large, acutely triangular, over the area of the epiproct, with the apex obtusely concave and sides strongly sclerotized. Next to each side of the shelf, and over the area of each paraproct, arise two pairs of sclerotized projections, an inner pair, long, slender, each arm running parallel to each side of the central shelf, with apices dilated, denticulate, and bearing throughout their length a row of setae; outer pair of projections smooth, wider basally, narrowing distally, acuminate, each arm running along the outer edge of each paraproct (Figure 3). Epiproct large, forming a sclerotized arch, with fields of papillae basally on each inner corner, bearing a row of four strong setae along the inner edges, two strong setae posteriorly on the inner edge of the arch and a row of three setae along the posterior border; middle area of the arch membranous, bearing a large, quadrate field of papillae (Figure 3).

Type species. $A$. ariasi new species.

Etymology. The generic name is a compound word, formed with the root of Amazonas, and Lachesilla, in reference to the origin of this genus, in the Brazilian state of Amazonas.

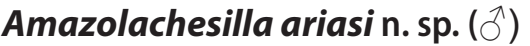

(Figures 1-5)

Color (after 31 years in $80 \%$ ethyl alcohol). Body yellowish pale. Compound eyes black. Legs and antenna pale yellowish brown. Thorax pale brown. Wings unmarked, with a faint orange wash. Abdomen whitish, genital segments yellowish. 

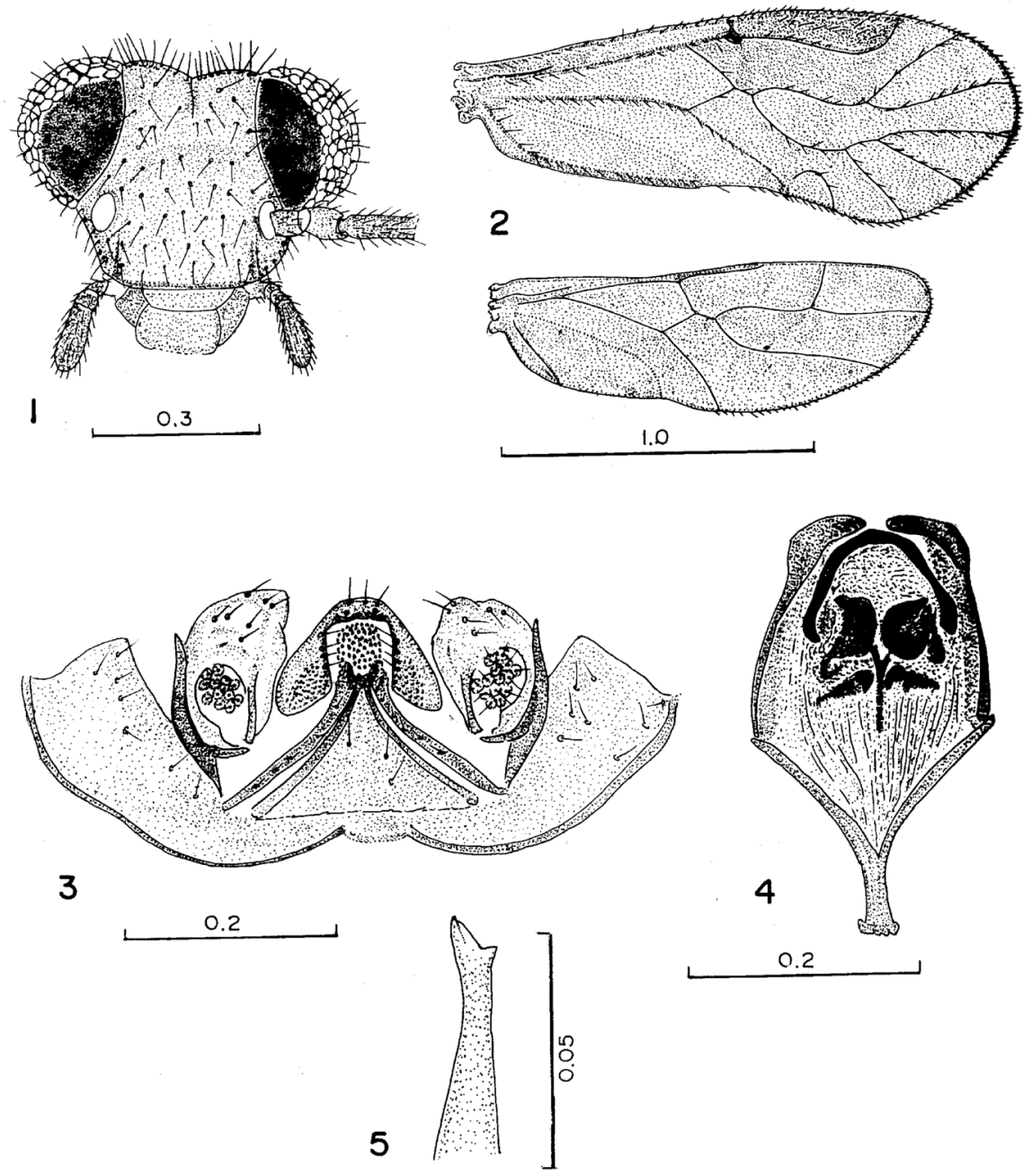

Figures 1-5 - Amazolachesilla ariasi n. gen., n. sp. (§). 1. Front view of head. 2. Fore- and hind- wings. 3. Clunium (shelf and projections), epiproct and paraprocts. 4. Phallosome. 5. Lacinial tip. Scales in $\mathrm{mm}$.

Morphology. As in generic diagnosis, plus the following: Compound eyes with setae between facets. Head (Figure 1 ). Lacinial tip (Figure 5). Wings (Figure 2). Clunium and epiproct (Figure 3 ). Phallosome (Figure 4). Paraprocts (Figure 3), broad, setose as illustrated, with a distinct, longitudinal sclerotized rod next to sensory field, joining proximal end of outer projection of clunium; sensory fields with 13-14 trichobothria issuing from basal rosettes.

Measurements. FW: 1964, HW: 1262, F: 471, T: 750, t1: 274, t2: 87, ctt1: 17, Mx4: 150, f1: 353, f2: 241, f3: 193, f4: 180, f5: 176, IO: 234, D: 288, d: 185, IO/d: 1.26, PO: 0.64 .

Type material. Brazil. Amazonas. Rodovia AM 010, km

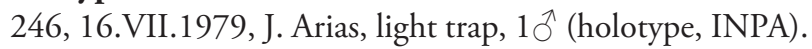

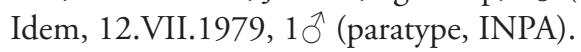

Etymology. The specific name honors the collector of the two specimens available, Dr. Jorge Arias.

Comments. In the males of the genera of Eolachesillinae: Graphocaeciliini (Mockford and Sullivan 1986), the phallosome is anteriorly closed, rounded, at most with a short stem, or flat (Anomopsocus, Antilachesilla, Graphocaecilius, Notolachesilla and Prolachesilla), or it has a well defined basal stem (Mesolachesilla, Nanolachesilla, and Tricholachesilla). The structural similarities of the clunium around the bases of epiproct and paraprocts, the attachment of the aedeagal arch only in membrane, and the curvature of the external parameres around the arch, place Amazolachesilla n. gen., on the same branch as Tricholachesilla (see below); it differs from the other genera by several autapomorphies: a peculiar, triangular clunial shelf over the area of the epiproct, two distinct pairs of slender, 
long clunial projections, the uniqueness of the epiproct structure, and the well defined longitudinal, sclerotized rod of the paraprocts, that articulates basally with the second pair of clunial projections. It seems to stand closer to Tricholachesilla than to Mesolachesilla, based on line 7 of Mockford and Sullivan's (1986) dendrogram of possible phylogeny of the graphocaeciliine genera. Amazolachesilla n. gen., shares with Tricholachesilla the following character states: absence of ocelli, external cusp of lacinial tip shallowly bidentate, Rs fork stem of forewing slightly sigmoid, forewing ciliation, membrane of pterostigma with scattered setae, microtriches of hindwing margin, phallosome with a basal stem, external parameres articulated to lateral struts of the phallosome, and basal articulation of the aedeagal arch membranous. Tricholachesilla has the clunial shelf over the base of the epiproct of three parts: a median broad, rounded flap, with minute tubercles, and to each side a short process, followed by a projection over the base of each paraproct; the male clunio-epiproctal specializations seen in Amazolachesilla n. gen., and Tricholachesilla are similar enough to suggest that both genera may have arisen from a single common ancestor.

\section{Key to the graphocaeciliine genera of Amazonia}

1.- Areola postica of forewing fused with M; ocelli present Anomopsocus

-- Areola postica free; ocelli present or absent ..... .2

2.- Ocelli absent Graphocaecilius
3.- Base of phallosome flat; endophallic sclerites as minute denticles

-- Base of phallosome stemmed; endophallic sclerites larger Amazolachesilla

4.-Aedeagal arch projected posteriorly in the middle; external parameres narrowing distally. Prolachesilla.

-- Aedeagal arch rounded posteriorly; external parameres blunt ended. Notolachesilla

\section{ACKNOWLEDGMENTS}

We thank Dr. José Albertino Rafael and Augusto Henriques (Coleçáo de Invertebrados do INPA), for making available for study the Psocoptera in the INPA collection. The senior author (ANGA) thanks Felipe Villegas (Instituto de Biología, Universidad Nacional Autónoma de México) for technical support with the illustrations, and the latter institution for supporting his research over the years.

\section{REFERENCES}

García Aldrete, A.N. 2006. New genera of Psocoptera (Insecta), from Mexico, Belize and Ecuador (Psoquillidae, Ptiloneuridae, Lachesillidae). Zootaxa, 1319: 1-14.

Mockford, E.L.; Sullivan, D.M. 1986. Systematics of the graphocaeciliine psocids with a proposed higher classification of the family Lachesillidae (Psocoptera). Transactions of the American Entomological Society, 112: 1-80.

Recebido em 23/08/2010

Aceito em 18/09/2010 